\title{
A special issue of
}

Science in Context

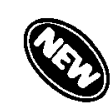

\section{On Medieval and Renaissance Cosmology}

Contents:

Feldhay on Knowledge and Salvation in Jesuit Culture

North on Double Truth in Medieval Discourse

Wolff on Impetus Mechanics and Copernicanism

Høyrup on Mathematics and Medieval Islam

Sylla on The Oxford Calculators and Scholastic Teaching

\section{DUHEM (RE)CONSIDERED}

Gurevich on Duhem and Medieval Culture

Livesey on Duhem's System of the World

Duhem: Autobiographical Assessment of his

Research (1913)

(Previously untranslated text)

Subscriptions for Volume 1, March and September, 1987 $£ 33.00$ (\$65) for institutions; $£ 19.00$ (\$37) for individuals; single parts $£ 17.00$ (\$33); Airmail $£ 6.50$ per year extra

To order your copy send payment to:

The Journals Subscription Manager, Cambridge

University Press, The Edinburgh Building, Shaftesbury

Road, Cambridge CB2 2RU, England, or The Journals Subscription Manager, Cambridge University Press, 32 East 57th Street, New York, NY 10022, U.S.A. 


\section{Science Progress}

\section{a review journal of current scientific advance}

\section{EDITORS}

\section{Professor J.M. Ziman FRS}

Departments of Social and Economic Studies and of Humanities, Imperial College, London

\section{Professor P.J.B. Slater}

Department of Zoology and Marine Biology, University of St Andrews

\section{Professor Patricia Clarke FRS \\ Cirencester}

Science Progress was first published in 1894, and its primary object has always remained the same - to publish articles written by experts to explain the latest developments in their own speciality to their colleagues working in other fields. Some of the most spectacular advances in science arise from the fusion of two or more disciplines, such as that of physics and chemistry with genetics to produce molecular biology. In this situation the journal's current practice of presenting non-specialist reviews is particularly valuable. It seeks as far as possible to emphasize current progress on the borderlines of the scientific disciplines in the hope that it may further the unification of science and stimulate scientists to think about problems outside their own immediate fields of interest.

\section{Subscription Information}

Science Progress is published quarterly. Subscription rates for 1987 are $£ 38.00$ (UK), $\$ 85.00$ (USA \& Canada), $£ 45.40$ (elsewhere) post free.

\section{Order Form}

Please tick the appropriate box and return to Blackwell Scientific Publications Ltd, P.0. Box 88, Oxford, England.

$\square$ I would like to subscribe to Science Progress

I wish to pay by cheque/money order (delere as necessary/ and enclose the sum of

I wish to pay by Access/Barclaycard/VISA/Mastercard (delete as necessary)

Please debit my credit card no.

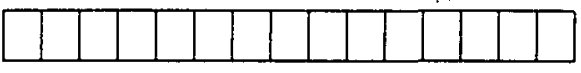

Expiry date. with the sum of

Signature. Date

Please send me a spccimen copy of Science Progress

Name.

Address 


\section{Academic Printing \& Publishing}

\section{Ancient Philosophy from A.P.P.}

\section{Justice, Law, and Method in Plato and Aristotle}

Edited with an Introduction by Spino Panagiotou

A volume of original essays. The essays discuss obedience to law in the Crito, Glaucon and Adeimantus in the Republic, justice and method in the Statesman, and the topics of Corrective Justice and Equity in Aristotle. Contributors: Brian Calvert, Spiro Panagiotou, Reginald E. Allen, Thomas M. Robinson, Michael C. Stokes, Brad Inwood, Kenneth Dorter, David L. Hitchcock, Ernest J. Weinrib, Wilfrid J. Waluchow, Constantine Georgiadis, Roger A. Shiner.

180 pp Cloth \$35.95 0-920980-18-X Paper \$17.95 0-920980-20-1

\section{Aristotle Today}

Edited with an Introduction by Mohan Matthen

A collection of previously unpublished essays at the forefront of contemporary scholarship.

Contents: Francis Sparshott, 'Aristotle's World and Mine' Jonathan Barnes, 'An Aristotelian Way with Scepticism' Montgomery Furth, 'Aristotle on the Unity of Form'

S. Marc Cohen, 'The Credibility of Aristotle's Philosophy of Mind' Alan Code, 'Metaphysics and Logic'

Mohan Matthen, 'Substance as Hylomorphic Complex'

Annotated index of passages discussed in detail; index locorum; index nominum; index topicorum.

170 pp Cloth \$36.95 0-920980-17-1 Paper \$18.95 0-920980-19-8

\section{APEIRON: a journal for ancient philosophy and science}

Executive Editor: Roger A. Shiner

Editorial Board: Richard N. Bosley, John King-Farlow, Mohan Matthen,

Francis Jeffry Pelletier, Janet D. Sisson, Martin Tweedale

A journal for high-quality scholarly research in the philosophy and science of the classical period.

APEIRON is now edited by members of the Department of Philosophy, University of Alberta, and published by A.P.P. At present two issues are published per volume.

Subscription price for Volume XX (1987)

All subscriptions: Cdn $\$ 22.00$ (Canadian)

US $\$ 22.00 / \mathrm{Cdn} \$ 29.00$ (non-Canadian)

\section{Order from: Academic Printing \& Publishing P.O. Box 4834 \\ Edmonton, Alberta, Canada T6E 5G7}

or from your usual bookstore or subscription agent. 


\section{The Development of Anaesthetic Apparatus}

A history based on the Charles King Collection of the Association of Anaesthetists of Great Britain and Ireland

\section{K. Bryn Thomas fFarcs}

From the reviews

'There is no other catalogue in the history of medicine akin to this one for it acts as a history of anaesthetics and of instrumental ingenuity, and at the same time is a scholarly guide to the artefacts themselves.' Medical History

'It has been well done, wonderfully illustrated, and is worthy of a medical historian of Dr Bryn Thomas's reputation.' British Medical Journal

'Serious work of scholarship though this is, Dr Bryn Thomas has enlivened it with many delightful asides ... and has included so much background material as to make it a treasure house of anaesthesiological information and lore catering for all tastes and prejudices.'

History of Medicine

1975. 280 pages, 233 illustrations. $£ 27.50 \quad 0632001771$

\section{Blackwell Scientific Publications}

Osney Mead, Oxford OX2 OEL, England

If you would like to update your corporate image, promote your product or service, or have an educational or training film made by a competent and imaginative team of professionals, read on.

Blackwell Videotec has years of experience in the corporate video world, specialising in the technical, scientific and research areas.

To support the film or video we also offer a full publishing service under the BV-Blackwell name.

A member of the Oxford based Blackwell publishing group, our name guarantees an authoritative corporate presentation.

Blackwell Videotec Limited Film and Video Production 7 John Street London WC1N 2ES

Tel: 0143000444301918 Contact: Solomon Nwabueze

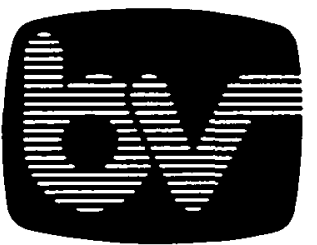


The British Journal for the History' of

Science

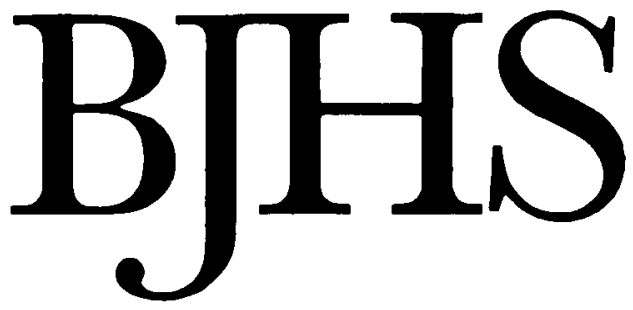

Editor DAVID KNIGHT

Department of Philosophy

University of Durham

50 Old Elvet

Durham DH1 $3 H N$

\section{Editorial ROBERT BUD \\ Science Museum \\ Board South Kensington \\ London SW7 2DD}

\section{JOHN CHRISTIE}

Department of Philosophy

The University of Leeds

Leeds LS2 9JT

MICHAEL SHORTLAND

Department for External

Studies

Rewley House

Wellington Square

Oxford OX12JA

JOHN HENDRY

(Book Review Editor)

58 Canfield Gardens

London NW6 $3 E B$

Volume 20

\author{
MICHAEL HUNTER \\ Department of History \\ Birkbeck College \\ University of London \\ Malet Street \\ London WCIE 7 HX
}

JOHN THACKRAY

The Geological Museum

Exhibition Road

London SW7 2DE

ROD HOME

Department of History o

Philosophy of Science

University of Melboume

Parkville, Victoria

Australia 3052

Published for

ISSN The British Society for the History of Science

0007-0874 by Blackwell Scientific Publications 
Published for the British Society for

the History of Science by

Blackwell Scientific Publications

Osney Mead, Oxford OX2 OEL

8 John Street, London WCIN $2 E S$

2.3 Ainslie Place, Edinburgh EH3 6AJ

52 Beacon Street, Boston, Massachusetts 02108 , USA

667 Lytton Avenue, Palo Alto, California 94301,

USA

107 Barry Street, Carlton, Victoria 3053, Australia

Printed in Great Britain

at The Alden Press, Oxford

(1) 1987 British Society for the History of Science.

The British Society for the History of Science retains copyright for all articles published: it is the author's responsibility to secure any necessary permission for publication. Single copies of articles may be made for research or private study without further ado. Permission to make multiple copies should be obtained from the Society 


\section{Contents}

VOLUME 20 PART I JANUARY 1987

1 Foreword

3 David Knight: Background and Foreground: Getting Things in Context

13 William Montgomery: Editing the Darwin Correspondence: A Quantitative Perspective

29 Nathan Reingold: On Not Doing the Papers of Great Scientists

39 Reese V. Jenkins: Words, Images, Artifacts and Sound: Documents for the History of Technology

57 John Stachel: 'A Man of my Type'-Editing the Einstein Papers

67 A. J. Meadows: Changing Records and Changing Realities

73 Frank G. Burke: Automation and Documentary Editing

81 Book Reviews

126 Books Received

VOLUME 20 PART 2 APRIL 1987

129 Evelleen Richards: A Question of Property Rights: Richard Owen's Evolutionism Reassessed

173 Michael Shortland: Courting the Cerebellum: Early Organological and Phrenological Views of Sexuality

201 Graham Richards: Of What is History of Psychology a History? Essay Review

213 Andy Pickering: Forms of Life: Science, Contingency and Harry Collins

223 Book Reviews

239 Books Received 
VOLUME 20 PART 3 JULY 1987

241 Isobel Falconer: Corpuscles, Electrons and Cathode Rays: J. J. Thomson and the 'Discovery of the Electron'

287 Maurice Crosland: The Image of Science as a Threat: Burke versus Priestly and the 'Philosophic Revolution'

319 James R. Hofmann: Ampère's Invention of Equilibrium Apparatus: A Response to Experimental Anomaly

353 H. A. M. Snelders: History of Science Today, 2. History of Science in the Netherlands

\section{Obituaries}

359 Joan Mary Eyles, née Biggs: 1907-1986

360 Niels Hugh de Vaudrey Heathcote: 22 January 1895-23 June 1985

363 Book Reviews

$371 \quad$ Books Received

VOLUME 20 PART 4 OCTOBER 1987

375 Editorial

377 Gerard L'E. Turner Presidential Address: Scientific Toys

399 Robert Olby: William Bateson's Introduction of Mendelism to England: A Reassessment

421 Michael Shortland: Screen Memories: Towards a History of Psychiatry and Psychoanalysis in the Movies

453 R. Hooykaas: The Rise of Modern Science: When and Why?

475 Book Reviews

$488 \quad$ Books Received

$490 \quad$ Index of Books Reviewed

493 Report of Council for 1986-1987 


\section{THE BRITISH SOCIETY FOR THE HISTORY OF SCIENCE}

Membership of the Society, which includes a subscription to The British Journal for the History of Science, is open to all persons approved by the Council of the Society and elected at an ordinary mecting (formalitics required by the UK Companies Act). The annual subscription for the membership year $1986-1987$ is $£ 13.5^{\circ}$ (US $\$ 27.00$ in the Americas, Canada and Japan) or for students, $\AA^{6.75}$ ( $\left.\$ 13.50\right)$. Applications for membership should be made on a form which is available from the Society's Exccutive Secretary at the address below.

Meetings: The Society mounts an ambitious programme of meetings. The pattern is flexible, the only fixture being the three day summer meeting, held at a different British University or Polytechnic cach year. About four other meetings, lasting for between one and three days, are held during the year, sometimes devoted to a clearly-defined theme or an important anniversary, and often arranged in conjunction with other scholarly societies.

The British Journal for the History of Science is the official organ of the Society. All correspondence on the contents of the Journal should be addressed to the Editor, Dr David Knight, Department of Philosophy, University of Durham, 50 Old Elvet, Durham DH $13{ }_{3} \mathrm{HN}$, England.

Books for review should be sent to the Reviews Editor, Dr John Hendry, 58 Canficld Gardens, London NW6 ${ }_{3} \mathrm{~EB}$.

Advertising: Contact the Advertising Department, Blackwell Scientific Publications, Osney Mead, Oxford, OX2 oEL. Fax no. (0865) 721205.

Other publications: BSHS Monograph Scries is designed to allow the publication of monographic studies in the history of science quickly and cheaply. All correspondence on the subject of monographs, and any new suggestions for titles, should be scnt to the Scries Editor, Dr J. G. Smith, Department of History, University of Loughborough, Loughborough, Leics LE I 3 TU, England. Monographs are available to members at a special price, post-frec from the Socicty's Exccutive Secretary. Non-members may obtain them through bookshops, or post-frec from the Exccutive Sccretary. Now available:

1. Images of the Earth: Essays in the History of the Environmental Sciences. Ed. by L. J. Jordanova and Roy Porter. $1979 \cdot £ 7.50 / \$ 15.00$ ( $£ 5.00 / \$ 10.00$ to members).

2. The Letters of Georges Cuvier: A Summary Calandar. Ed. by Dorinda Outram. $1980 . £_{4.50 / \$ 9.00}$ (£3.5\%/\$7.00 to members).

3. Rationality and Ritual: The Windscale Inquiry and Nuclear Decisions in Britain. By Brian Wynne. $£ 7.00 /$ Si $4.00($ ( $5.00 / \$ 10.00$ to members).

4. The Royal Society and Its Fellows I660-1700: The Morphology of an Early Scientific Institution. By Michacl Hunter. $\mathcal{E}_{9.00 / \$ 18.00}\left(\mathcal{E}^{6.50 / \$ 13.00}\right.$ to members).

5. Francis Bacon's Natural Philosophy: A New Source. A Transcription of Manuscript Hardwick $72 A$ with Translation and Commentary. By Graham Recs, assisted by Christopher Upton. $£ 7.90 / \$ 15.50(£ 5.60)$ $\$ 11.00$ to members).

List of theses: Every December, the Socicty publishes a full list of current theses in history of science in British universities. This is available free to members, and at a small charge to non-members on request to the Executive Secretary. Standing orders are accepted from members or non-members who wish to receive the list regularly.

The Society's Newsletter, an informal publication edited by Dr Mari Willians, Business History Unit, Lionel Robbins Building, Io Portugal Street, London $\mathrm{WC}_{2} \mathrm{~A}{ }_{2} \mathrm{HD}$, appears in January, May and September cach year. It is free to members, $£ 4.50$ for institutions and non-menbers.

All the administrative business of the Society is handled by The Executive Secretary, WingCommander G. Bennett, 'Southide', 31 High Street, Stanford-in-the-Vale, Faringdon, Oxfordshire $\mathrm{SN}_{7} 8 \mathrm{LH}$. 
The British

Journal

for the

History of

Science
Volume 20

Part ${ }_{4}$ No. 67

\section{October 1987}

375 Editorial

377 Gerard L'E. Turner: Presidential Address: Scientific Toys

399 Robert Olby: William Bateson's Introduction of Mendelism to England: A Reassessment

42 I Michael Shortland: Screen Memories: Towards a History of Psychiatry and Psychoanalysis in the Movies

453 R. Hooykaas: The Rise of Modern Science: When and Why?

475 Book Reviews

488 Books Received

$490 \quad$ Index of Books Reviewed

493 Report of Council for I 986- I987

Published for The British Society for the History of Science

by Blackwell Scientific Publications

Oxford $\cdot$ London $\cdot$ Edinburgh $\cdot$ Boston $\cdot$ Palo Alto $\cdot$ Melbourne

(C) The British Society for the History of Science 1987 